\title{
Scientific Drilling and Related Research in the Samail Ophiolite, Sultanate of Oman
}

\author{
by Peter Kelemen, Ali Al Rajhi, Marguerite Godard, Benoit Ildefonse, Jürgen Köpke, \\ Chris MacLeod, Craig Manning, Katsu Michibayashi, Sobhi Nasir, \\ Everett Shock, Eiichi Takazawa, and Damon Teagle
}

\section{Summary}

This workshop report describes plans for scientific drilling in the Samail ophiolite in Oman in the context of past, current, and future research. Long-standing plans to study formation and evolution of the Samail crust and upper mantle, involving igneous and metamorphic processes at an oceanic spreading center, have been augmented by recent interest in ongoing, low temperature processes. These include alteration and weathering, and the associated sub-surface biosphere supported by chemical potential energy due to disequilibrium between mantle peridotite and water near the surface. This interest is motivated in part by the possibility of geological carbon capture and storage via engineered, accelerated mineral carbonation in Oman.

Our International Continental Drilling Program (ICDP) proposal led to the Workshop on Scientific Drilling in the Samail Ophiolite in Palisades, New York, on 13-17 September 2012. There were seventy-seven attendees from eleven countries, including twenty early career scientists.

After keynote presentations on overarching science themes, participants in working groups and plenary sessions outlined a U.S.\$2 million drilling plan that practically addresses testable hypotheses and areas of frontier discovery in the following areas.

- understanding the subsurface biosphere

- characterizing the rates and mechanisms of ongoing mineral hydration and carbonation

- characterizing chemical and physical processes of mass transfer across a subduction zone

- evaluating well-posed hypotheses on hydrothermal circulation, cooling, and emplacement mechanisms of igneous rocks in the lower crust

- investigating key problems in the dynamics of mantle flow and melt transport beneath oceanic spreading ridges

This report places these goals in the context of complementary research via ocean drilling and ongoing studies of active processes at oceanic spreading centers, subduction zones, and peridotite-hosted hydrothermal systems. We end with an outline of the synergy between Oman drilling and the specific drilling proposed in the Integrated Ocean Drilling Program (IODP) proposal "Mohole to Mantle Project (M2M)”, IODP Proposal 805-MDP.

\section{Workshop Proceedings and Results}

Keynote speakers outlined hypotheses and areas of frontier scientific exploration to be addressed via drilling, including

- the nature of mantle upwelling,

- the chemical and physical mechanisms of mantle melt transport,

- the processes of lower crustal accretion and cooling,

- the frequency and magnitude of microseismicity during weathering,

- the rate and location of ongoing alteration, and

- the composition, density, and spatial distribution of subsurface microbial communities.

Additional keynote talks covered state-of-the-art geological logging of drillcore, geophysical logging in boreholes, and data management.

Breakout groups considered overarching science themes, then designed idealized projects to address these themes,

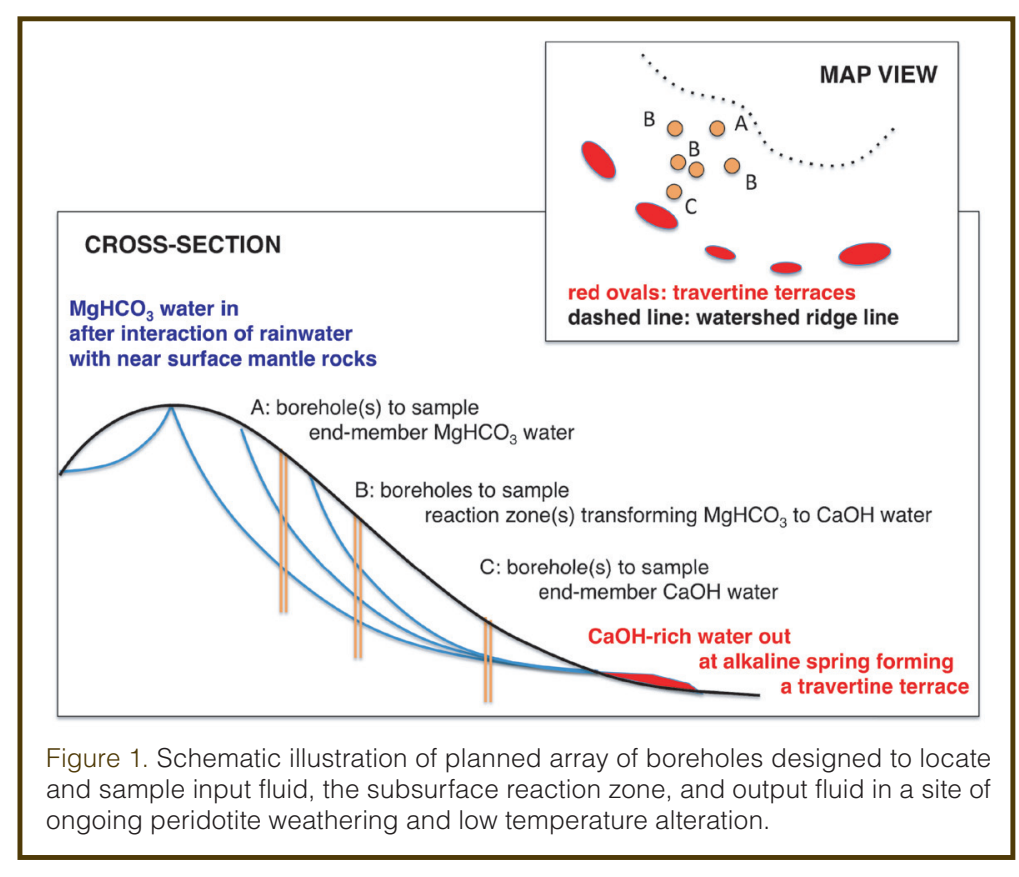


and finally considered practical constraints. We agreed to focus on studies relevant to global processes. There was a consensus that to achieve the desired goals for this project, core must be logged to the IODP standard by dedicated science teams, and there must be extensive geophysical logging and experiments in boreholes. We planned for individual holes extending to a maximum of $600 \mathrm{~m}$ using local drilling technology and expertise, reasoning that current understanding of variation with depth does not warrant the extra expense required to import specialized equipment and engineers required for deeper holes. After wireline diamond drilling with continuous coring, it will be necessary to widen some holes or to drill parallel holes without coring, by rotary-drilling in order to obtain the $\sim 15-\mathrm{cm}$ diameter required for many geophysical logging tools and likely downhole experiments.

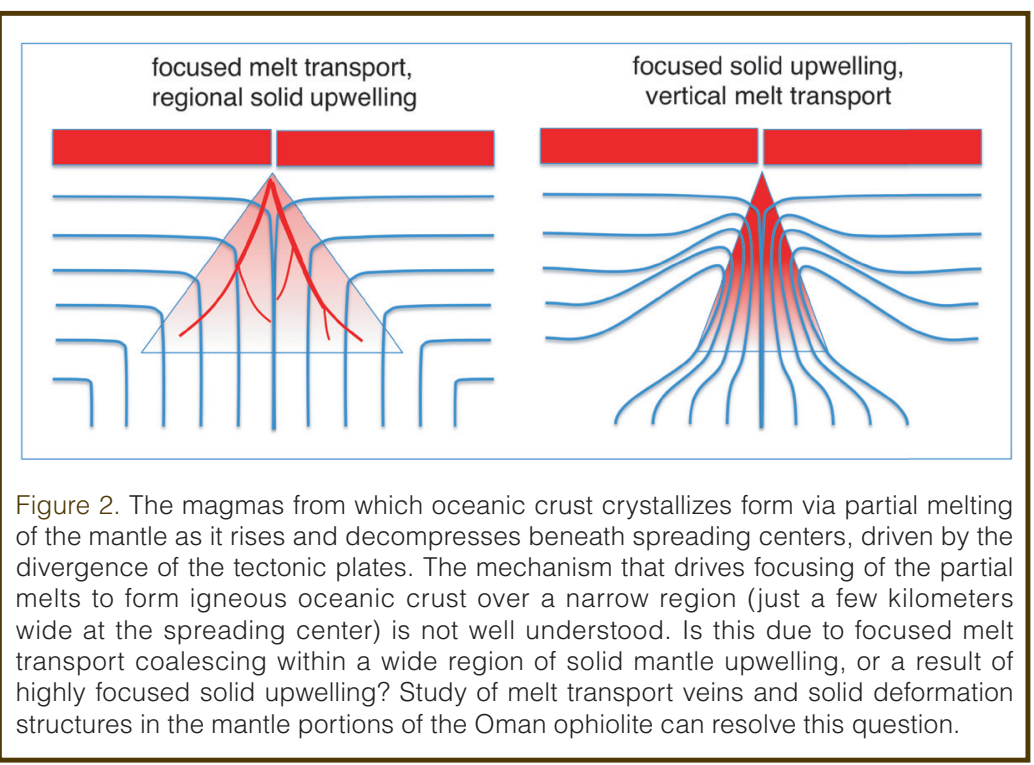

We derived an approximate value of USD \$250 per meter for continuous coring, based on approximate, informal estimates from two contractors operating in Oman. Using this estimate, the three final breakout groups were charged with designing a "Phase I" drilling program costing USD $\$ 2$ million. In a striking demonstration of consensus, all three recommended similar plans. Despite interest in the more complex, polygenetic northern massifs of the ophiolite, all three groups focused on drilling in the simpler southern massifs during Phase I.

To investigate active peridotite weathering, all three groups favored drilling multiple holes of moderate length in a peridotite catchment hosting alkaline springs to locate reaction zones where $\mathrm{MgHCO}_{3}$ ground water is transformed to $\mathrm{CaOH}$ alkaline water (Fig. 1). A few holes would later be deepened to investigate the variation of processes with depth, and widened to permit geophysical logging and downhole experiments. "Clean" rotary holes, drilled using air or high purity drinking water as lubricants, might be used to supplement diamond-cored holes to allow for easier and more accurate characterization of fluid compositions and the subsurface biosphere.

All groups prioritized 600-m holes through key transitions in the ophiolite: the dike-gabbro transition, the crust-mantle transition, and the basal thrust. They also prioritized 600-m holes in selected parts of the more homogeneous lower crustal gabbro and mantle sections. Some of these would be widened for logging to learn the nature of gaps in core recovery and allow for regional characterization of variability in hydrology, fluid composition, and subsurface biosphere as a function of lithology and location. All groups recommended that some of these longer "lithology" holes should be supplemented by shorter holes to characterize the nature and extent of lateral heterogeneity.

A popular idea among workshop participants was to send both core and scientists to use the IODP research drilling vessel JOIDES Resolution (JR) during the time that the vessel is in port (approximately four months per year). In addition to the efficiency of using the dedicated core logging facilities on the JR, this idea appealed to us because it would include housing, meals, and potential 24-hour operations for a science party dedicated to the task at hand. This plan is incorporated in our full proposal to the ICDP.

\section{Processes at Oceanic Spreading Centers}

The Samail ophiolite, in the Sultanate of Oman and the United Arab Emirates, is the world's largest subaerial exposure of oceanic crust and upper mantle. As for other ophiolites, the presence of continuous layers of pelagic and metalliferous sediments, submarine lavas, sheeted dikes, and cumulate gabbros overlying residual mantle peridotite is similar to crust formed at intermediate- to fast-spreading, mid-ocean ridges (Nicolas et al., 2000). Geochemical data suggest that the crust also has affinities with magmatic rocks in back-arc or fore-arc basins (Koepke et al., 2009; Pearce et al., 1981). The ophiolite has long been a testing ground for hypotheses about processes at spreading centers, including the following.

- ductile flow in the upper mantle (focused vs. plate-driven upwelling; Fig. 2)

[Ceuleneer et al., 1996; Nicolas and Violette, 1982]

- melt extraction and transport in the mantle (cracks vs. porous conduits)

[Braun and Kelemen, 2002; Kelemen et al., 1995; Nicolas, 1986]

- accumulation of melt in the crust-mantle transition zone

[Boudier and Nicolas, 1995; Korenaga and Kelemen, 1997]

- deformation of the lower crust (gabbro glacier vs. sheeted sills; Fig. 3) 
[Kelemen et al., 1997; Nicolas et al., 1988]

- near-ridge hydrothermal circulation and alteration (shallow vs. deep; Fig. 4)

[Bosch et al., 2004; Coogan et al., 2002; Manning et al., 2000; VanTongeren et al., 2008]

- melt transport, porosity, and crystallization in lower crustal cumulates

[Korenaga and Kelemen, 1998; Nicolas and Ildefonse, 1996]

- freezing, intrusion, stoping, and metamorphism at the dike-gabbro transition (Fig. 5)

[Boudier and Nicolas, 2011; France et al., 2009; MacLeod and Rothery, 1992; MacLeod and Yaouancq, 2000]

- formation of chemical layering within the volcanic section

[Alabaster et al., 1982; Godard et al., 2003]

Given the evident similarities and differences between the Samail ophiolite and mid-ocean ridges, investigations of the Samail ophiolite have generated hypotheses about ridge processes that are tested via seagoing research, and in turn observations from the oceans lead to refinement or modification of ideas about the ophiolite.

Proposed investigations in drillcore samples of the Oman mantle section include studies combining geochemistry to characterize mantle heterogeneity and crystallographic pre- ferred orientations indicative of solid state mantle flow trajectories, and studies of the relative age and spatial relationships of melt transport features. The results will allow us to evaluate the nature and importance of "mantle diapirs" in Oman and to test hypotheses for the processes by which partial melt from a region hundreds of kilometers wide in the mantle is focused into a $2-4 \mathrm{~km}$-wide zone of crustal accretion along oceanic spreading ridges (Fig. 2).

Analyses of drillcore from the Oman lower crust will be used to address well-posed, long-standing, unresolved questions. These pertain to (1) the extent of porous flow versus magmatic injection in dikes and sills, (2) the extent of solid-state versus crystal mush deformation of the lower crust and its variation with depth in the crustal section (Fig. 3), (3) the modification of lower crustal composition during hydrothermal alteration, (4) the transition from relatively coarse gabbros to fine-grained sheeted dikes, and (5) the role of fluids in controlling the nature and rate of cooling of the lower crust. These factors provide the primary controls on heat and mass input from the mantle to the oceans, but their extent and interplay remain controversial after decades of discussion. Study of the pattern of chemical variation with depth, the extent of crystallographic preferred orientation, and zoning within minerals indicative of cooling rates over a variety of different temperature intervals should provide clear resolution of these issues, or at least comprehensive constraints on remaining hypotheses.
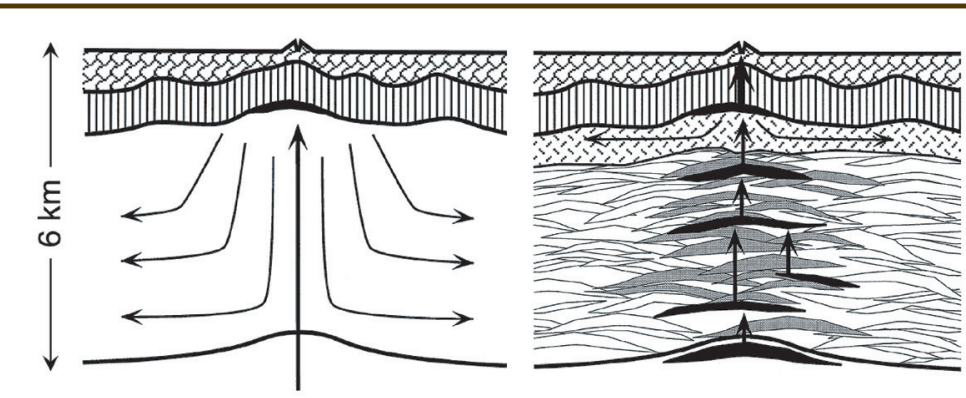

lavas
dikes
upper
gabbro
lower
gabbro
Moho

Figure 3. The lower oceanic crust forms from subsurface crystallization of igneous rock beneath spreading centers, forming gabbros. The site of crystallization is poorly known. Does all of the crystallization occur in a "shallow melt lens" near the surface, where heat can be extracted efficiently, after which gabbros undergo ductile flow downward and outward (left), or do gabbros crystallize in many stacked melt lenses throughout the crust (right)? Studies of chemical variation and crystal orientation in the lower crust of the Oman ophiolite can resolve this question. Modified from Kelemen et al. (1997).
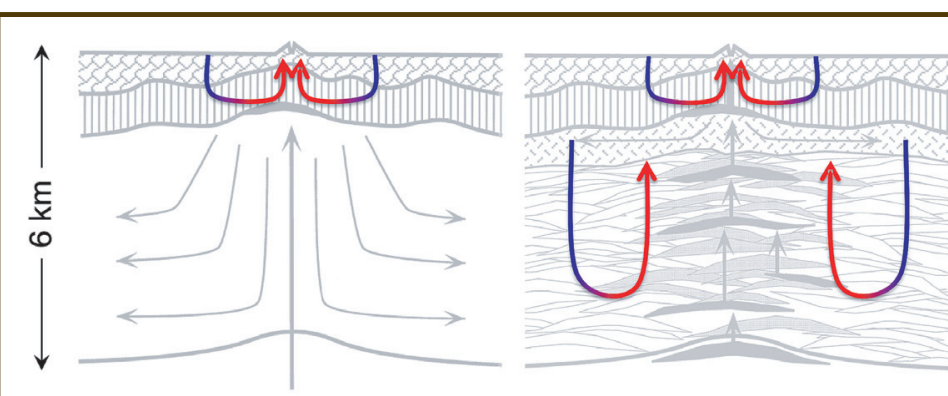

lavas
dikes
upper
gabbro
lower
gabbro
Moho

Figure 4. Crystallization of gabbros in a shallow melt lens requires rapid removal of heat by hydrothermal convection in the upper crust. Crystallization of gabbros at a range of depths requires hydrothermal circulation down to the base of the crust. Measurement of mineral zoning in Oman gabbros, interpreted in terms of cooling rates, will resolve which was predominant.

\section{Mass Transfer into the Shallow Mantle above Subduction Zones}

A close correspondence between 96-95-Ma igneous ages in the crust, and the oldest ages of metamorphic rocks along the basal thrust ( 95-94 Ma), indicate that thrusting of the ophiolite over adjacent oceanic crust and nearby sedimentary rocks began during or immediately after initial formation of igneous crust (Rioux et al., 2012a, 2012b). Metamorphic rocks emplaced along the basal thrust, between overlying peridotite and underlying metasediments, record hot subduction zone conditions up to $800^{\circ} \mathrm{C}-900^{\circ} \mathrm{C}$ and 650 $900 \mathrm{MPa}$ (Ghent and Stout, 1981; Hacker and Gnos, 1997). In some localities at much shallower depths and lower temperatures, hanging wall peridotites underwent 100\% carbonation at $100^{\circ} \mathrm{C}-200^{\circ} \mathrm{C}$ to form rocks composed entirely of magnesite + quartz + chromite (Kelemen et al., 2011; Fig. 6), suggesting that the "leading edge of the mantle wedge" may be a globally important, hitherto unappreciated reservoir for carbon. 
Mapping and sampling outcrops of the basal thrust, spanning the contact between metasediments and the overlying mantle (Fig. 7), will allow direct study of chemical and physical processes of mass transfer in a subduction zone. Because the thrust beneath the Samail ophiolite was young and hot, observations there will be interpreted in the context provided by investigations of other settings, especially along active subduction zones in different stages of evolution. In the context of research to be
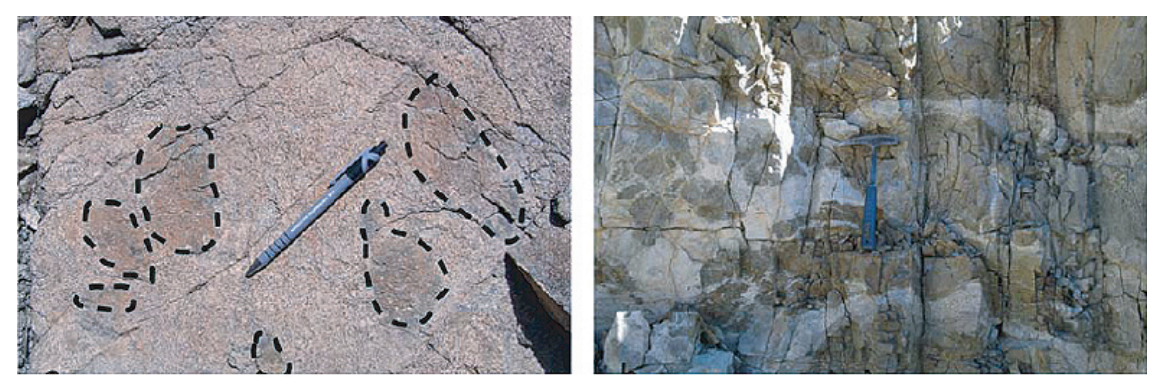

Figure 5. Gabbros intruding and stoping blocks of hydrothermally altered sheeted dikes in the Wadi Gideah section of the Wadi Tayin massif. Studies of such dike-gabbro transitions wil provide essential information on the nature of heat and mass transfer between oceanic lower crust, upper crust, and the oceans. From France et al. (2009). addressed via drilling in Oman, ideas and observations outlined above can be quantified via detailed 1-D geochemical and structural transects in drillcore(s), combined with detailed mapping of the surrounding 3-D geology. Of particular interest will be identifying the footwall source(s) of carbon-rich fluids, the mechanical processes of fluid migration, the diffuse or localized nature of hanging wall alteration, the overall balance of low temperature mass transfer, the pressure and temperature range over which mass transfer was active, and the extent to which Oman observations can be extrapolated to subduction zones worldwide.

\section{Ongoing Weathering and Present-Day Hydrology}

Pioneering studies of peridotite-hosted alkaline springs (Neal and Stanger, 1985; Fig. 8a) and bedrock hydrology (Dewandel et al., 2005) in the ophiolite are now commonly-cited foundations for research on weathering of peridotites, focused primarily on mineral hydration (serpentinization), mineral carbonation, and generation of $\mathrm{H}_{2}$ and $\mathrm{CH}_{4}$ (Boudier et al., 2010; Kelemen et al., 2011; Oeser et al., 2012). Closed-system interpretation of ${ }^{14} \mathrm{C}$ data yields ages of $0 \mathrm{kyr}$ to $>50 \mathrm{kyr}$ for carbonate veins in serpentinized peridotites (Fig. 8b), with an average of about $26 \mathrm{kyr}$, and a similar range in ages of travertine terraces at alkaline

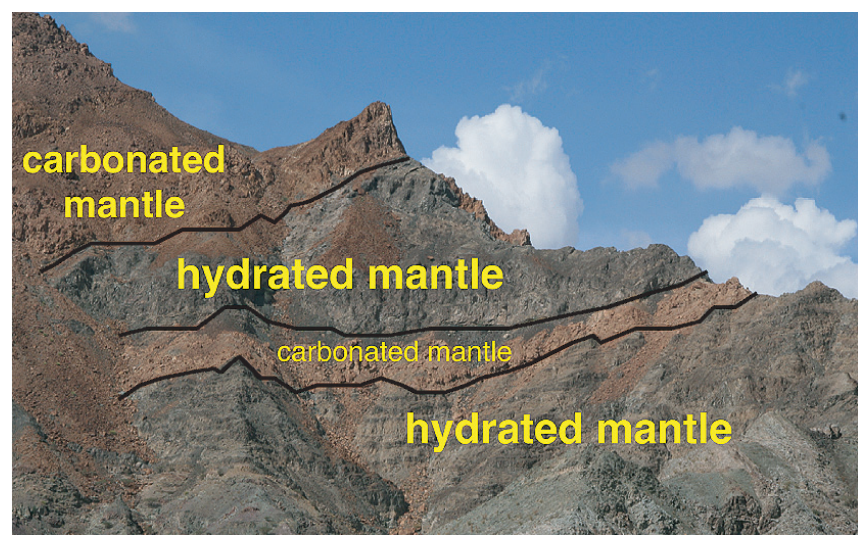

Figure 6. Fully carbonated lenses (magnesite + quartz + chromian spinel) within partially serpentinized mantle peridotite, near the base of the Samail mantle section where peridotites were thrust over metasediments. The lenses are parallel to the basal thrust. The thinner lower lens is about $10 \mathrm{~m}$ thick; the thicker upper lens is about $200 \mathrm{~m}$ thick. Together, they contain about one billion tons of $\mathrm{CO}_{2}$ in solid carbonate minerals. springs (Clark and Fontes, 1990; Kelemen and Matter, 2008; Kelemen et al., 2011). These young ages are consistent with mineral thermometry indicating near-surface crystallization at $20^{\circ} \mathrm{C}$ to $60^{\circ} \mathrm{C}$ (Streit et al., 2012), and with observations of alkaline spring water (Paukert et al., 2012), demonstrating that subsurface serpentinization and mineral carbonation are active, ongoing processes in Oman. Perhaps this is not surprising, given the huge reservoir of chemical potential energy represented by outcrops of peridotite far from equilibrium with the high $\mathrm{fO}_{2}, \mathrm{fH}_{2} \mathrm{O}$ and $\mathrm{fCO}_{2}$ in the atmosphere and surface waters. Presumably, the resulting steep chemical gradients, particularly in redox potential, support an abundant and unique subsurface microbial ecosystem, but in Oman this is essentially terra incognita, and studies of similar niches elsewhere have yielded strikingly low cell densities and species diversity (D. Cardace, M. Schrenk, A. Templeton, I. Tiago, pers. comm., 2012).

\section{Biogeoscience}

There is increasing recognition that investigating ongoing alteration and the related subsurface microbial ecosystem in the Samail ophiolite holds as much promise-for contributing to fundamental understanding of global processes-as studying the Cretaceous formation and evolution of oceanic plates in Oman. On-land studies will complement observations from similar, submarine systems. Thus, proposed IODP drilling of Atlantis Massif in the vicinity of the Lost City hydrothermal system (IODP Proposal 758-Full2), a site of ongoing peridotite alteration near the Mid-Atlantic Ridge, will form a fertile partnership with studies of similar systems in Oman.

Investigations of ongoing alteration and the associated subsurface biosphere are ideally suited to studies of cores and in boreholes. Cores will be used to observe the vertical extent and distribution of vein lithologies and diffuse alteration, small-scale variation of fracture density and permeability, and the pore-scale habitat of microbial communities. Downhole measurements and fluid sampling will determine the multi-scale variation of fluid composition and flow, crackaperture, porosity, permeability, temperature, stress, microbial density, and species diversity. In-hole experiments will determine geochemical transport properties and allow 
microbial culture and incubation experiments. Hole-to-hole measurements will characterize the nature and frequency of natural fracture events due to volume changes during ongoing alteration, changing temperature, and precipitation events. They will also monitor microseismicity induced by fluid injection for permeability and geomechanical measurements, and monitor the results of reactive tracer experiments.

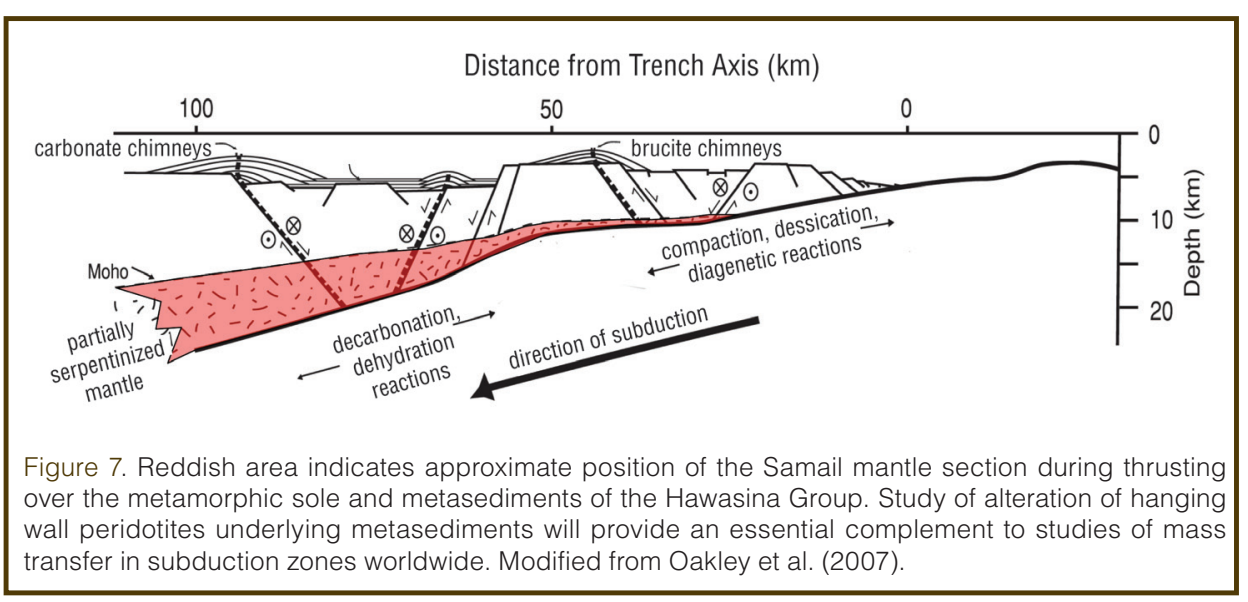

Again, this very specific list of achievable, observational goals can be placed in a broader context. The factors we will measure control mass transfer between the atmosphere, the hydrosphere, and the lithosphere in the near surface environment. They determine why some rocks preserve high temperature and pressure mineral equilibria, while others undergo complete hydration and carbonation to form mineral assemblages in equilibrium with surface waters, generating microbial habitats in the process. They control the rates of chemical and mechanical weathering and feedback between these processes.

From a biogeoscience point of view, there is plenty of energy available for chemosynthesis in Samail peridotites near the surface (Ménez et al., 2012; Okland et al., 2012; Schulte et al., 2006; Shock, 1996). And, strikingly, the combination of low $\mathrm{fO}_{2}$, reduced carbon species, and the presence of FeNi metal alloys (common during peridotite alteration) promotes abiotic synthesis of complex hydrocarbon species (McCollom et al., 2010). Why have studies of peridotite alteration environments elsewhere found so little life? Are there nutrient limitations, or toxic constituents? Have investigators looked in the wrong places, or is this energetic but geochemically extreme environment inaccessible along almost all available evolutionary pathways?

\section{Mineral Carbonation in Peridotite for Geological Carbon Capture and Storage}

The previous sections of this paper describe natural systems in which alteration has converted silicates in peridotite into $\mathrm{Mg}$-Ca carbonate minerals, both in a $\sim 200^{\circ} \mathrm{C}$ subduction zone setting and in the present day weathering environment. It has been proposed that understanding these natural mineral carbonation systems in Oman, which in some cases have formed carbonate minerals from all of the $\mathrm{Mg}$ and Ca present in peridotite protoliths, can provide insight into design of potential, engineered systems for geological capture and storage of carbon springs (Kelemen and Matter, 2008; Kelemen et al., 2011). It seems likely that reactions that increase solid mass and decrease solid density will grind to a halt, consuming porosity, destroying permeability, and armoring reactive surfaces with reaction products. However, the presence of fully carbonated and hydrated (serpentinized) peridotites demonstrate that this is not always the case.

Under what conditions do natural systems avoid these negative feedbacks and produce $100 \%$ carbonation? One key seems to be that, under some circumstances, increasing solid volume-due to addition of $\mathrm{H}_{2} \mathrm{O}$ and $\mathrm{CO}_{2}$, and to decreasing solid density-leads to increasing stress and fracture, which in turn provides continuing access for fluids to reactive mineral surfaces in a positive feedback mechanism that produces a network of fractures at the grain scale (Kelemen and Hirth, 2012). Understanding reaction-driven cracking is important for engineered, in situ mineral carbonation but also could be applied to extraction of unconventional hydrocarbon resources and improving geothermal power generation. However, the conditions that lead to runaway, reaction-driven cracking are poorly understood.

How might we engineer these conditions? What would be the environmental impacts of rapid, large-scale peridotite carbonation, for example, in terms of fluid composition and/or rock deformation?

More information on this topic can be found in the report of the Workshop on Geological Carbon Capture and Storage in Mafic and Ultramafic Rocks (see Related Web Links).

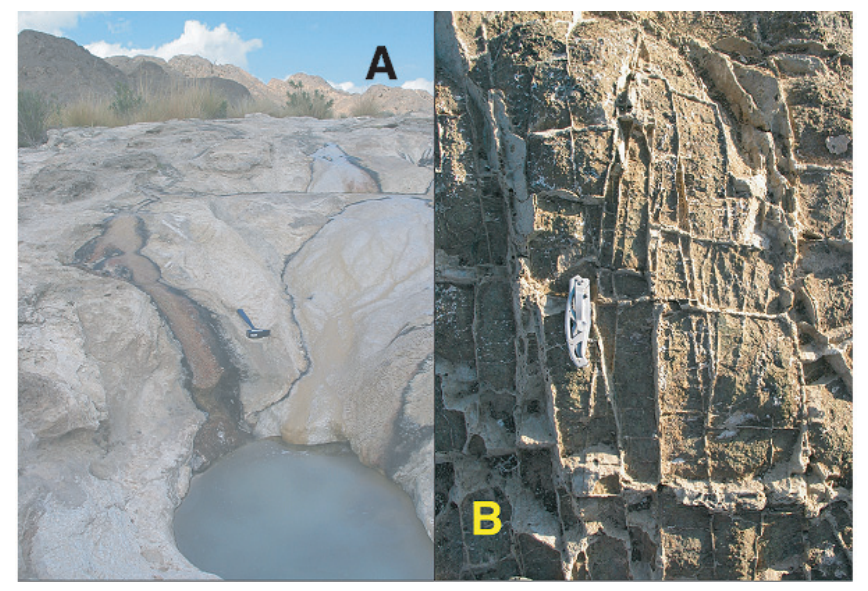

Figure 8. [A] Travertine at an alkaline spring in a peridotite catchment, near the village of Falaij, Oman. [B] Carbonate veins in serpentinized peridotite, near the town of Birkat al Mawz, Oman. 


\section{Synergy with the IODP Science Plan}

Finally, most of the proposed drilling within the Samail ophiolite and associated scientific objectives should be seen in the context of the IODP Science Plan 2013-2023 and the specific IODP drilling Proposal 805-MDP, which proposed the Mohole to the Mantle Project (M2M), for drilling a complete section of oceanic crust into the underlying mantle in the Pacific. While Oman drilling and ocean drilling into the mantle are very different in their overall scale, technological requirements, and associated budgets, they are also extremely complementary. Oman drilling provides an opportunity to evaluate IODP strategies at a relatively low risk. Scientists often ask, what can be learned from a one-dimensional sample through a three-dimensional object such as an oceanic plate? One clear and valid answer, of course, is that if you don't go, you won't ever know. But scientific drilling in the Samail ophiolite provides opportunities for a more subtle and quantitative response. In Oman, we can make observations in drillcore, and then in many cases map the surrounding three-dimensional geology at any desired scale. Thus, we can determine-just as a simple examplethe statistics of serpentine vein density in olivine in $100 \mathrm{~m}$ of drillcore, and compare them to the values for samples from surrounding outcrops with significant structural relief at a density of one sample (or 10, or 100, or 1000) per $\mathrm{km}^{3}$. Such comparisons can provide a statistically valid answer to the question, how representative is a single drillcore, and hence, help guide coring and offset hole strategies and the choice of geophysical logging techniques within a full crustal drill hole in the oceans.

Likewise, the hypothesis that ophiolites are closely analogous to in situ oceanic crust has often been challenged because most, if not all, ophiolites are believed to have formed in supra-subduction zone environments. Also, the Samail ophiolite was affected by thrust tectonics during or very soon after its formation. Yet, the layered structure of ophiolites, and particularly the Samail ophiolite, has been central to our paradigm for the structure of Pacific Ocean crust. How representative are specific features of ophiolites, with respect to "normal" oceanic crust formed at mid-ocean ridges such as the East Pacific Rise? This question can be dramatically addressed by sampling oceanic lower crust and upper mantle in the Pacific. This endeavor is one of the major challenges highlighted in the IODP Science Plan 2013-2023, and the topic of IODP Proposal 805-MDP. Meanwhile, we will continue the decades-long, highly productive dialogue in which ophiolite studies lead to hypotheses and issues best addressed by seagoing studies, and in which marine observations inform ongoing ophiolite research. Ophiolite drilling can provide a 3-D understanding of the scale of crustal and mantle heterogeneity that is difficult or impossible to achieve via ocean drilling. Drilling in Oman will use simple, locally available technology, at about two orders of magnitude lower cost than drilling through Pacific crust. By contrast, drilling through the crust and into the mantle in the Pacific will pro- vide unique samples from an environment that has never been visited, and which is more inaccessible and much less well known than the surface of the Moon.

\section{Conclusion}

Our workshop and the related full proposal to the ICDP have outlined a community consensus plan for scientific drilling in the Samail ophiolite in the Sultanate of Oman. Drilling will address long-standing, well-posed questions about the nature of solid upwelling and focused melt transport in the mantle beneath spreading centers, the igneous and metamorphic processes essential to the formation of oceanic lower crust in an intermediate- to fast-spreading environment, and ongoing processes of weathering and alteration of mantle peridotite exposed to reaction with surface waters. Understanding natural weathering processes, including mineral carbonation, can aid in future design of proposed engineered systems for geological carbon capture and storage and, more generally, design of systems using "reaction-driven cracking" to create a fracture network at the grain scale to extract unconventional hydrocarbon resources and improve geothermal power generation. We will explore the frontier area of microbial ecology within peridotite undergoing active alteration, with implications for abiotic hydrocarbon synthesis, the origin of life, and life in extreme environments. Oman drilling has synergies with IODP projects, including proposed drilling at the Lost City hydrothermal system in the Atlantic. It will provide an inexpensive and immediate opportunity to greatly optimize hole design, coring and logging programs for drilling into the mantle within Pacific ocean crust, and thus additionally provide a much needed context for reaping the maximum scientific benefits from that huge technical and financial endeavor in the future.

\section{Acknowledgements}

We thank the 87 participants in the Oman Drilling Workshop for their intellectual contributions and enthusiastic support of planned drilling in the Samail ophiolite. We are grateful to Uli Harms of ICDP for logistical support before and during the workshop, for encouraging us to prepare this paper, and for editorial suggestions. We also thank Hans Christian Larsen and other members of the editorial staff for helping us to improve this paper.

\section{References}

Alabaster, T., Pearce, J. A., and Malpas, J., 1982. The volcanic stratigraphy and petrogenesis of the Oman ophiolite complex. Contrib. Mineral. Petrol., 81(3):168-183. doi:10.1007/ BF00371294

Bosch, D., Jamais, M., Boudier, F., Nicolas, A., Dautria, J.- M., and Agrinier, P., 2004. Deep and high-temperature hydrothermal circulation in the Oman ophiolite: Petrological and isotopic evidence. J. Petrol., 45(6):1181-1208. doi:10.1093/ petrology/egh010

Boudier, F., and Nicolas, A., 1995. Nature of the Moho transition zone 
in the Oman ophiolite. J. Petrol., 36(3):777-796. doi:10.1093/ petrology/36.3.777

Boudier, F., and Nicolas, A., 2011. Axial melt lenses at oceanic ridges - A case study in the Oman ophiolite. Earth Planet. Sci. Lett., 304(3-4):313-325. doi:10.1016/j.epsl.2011.01.029

Boudier, F., Baronnet, A., and Mainprice, D., 2010. Serpentine mineral replacements of natural olivine and their seismic implications: Oceanic lizardite versus subduction-related antigorite. J. Petrol., 51(1-2):495-512. doi:10.1093/petrology/ egp049

Braun, M. G., and Kelemen, P. B., 2002. Dunite distribution in the Oman ophiolite: Implications for melt flux through porous dunite conduits. Geochem. Geophys. Geosyst., 3:8603. doi:10.1029/2001GC000289

Ceuleneer, G., Monnereau, M., and Amri, I., 1996. Thermal structure of a fossil mantle diapir inferred from the distribution of maficcumulates. Nature,379:149-153. doi:10.1038/379149a0

Clark, I. D., and Fontes, J.- C., 1990. Paleoclimatic reconstruction in northern Oman based on carbonates from hyperalkaline groundwaters. Quat. Res., 33(3):320-336. doi:10.1016/ 0033-5894(90)90059-T

Coogan, L., Jenkin, G. R. T., and Wilson, R. N., 2002. Constraining the cooling rate of lower oceanic crust: A new approach applied to the Oman ophiolite. Earth Planet. Sci. Lett., 199(1-2):127-146. doi:10.1016/S0012-821X(02)00554-X

Dewandel, B., Lachassagne, P., Boudier, F., Al-Hattali, S., Ladouche, B., Pinault, J.- L., and Al-Suleimani, Z., 2005. A conceptual hydrogeological model of ophiolite hard-rock aquifers in Oman based on a multiscale and a multidisciplinary approach. Hydrogeol. J., 13(5-6):708-726. doi:10.1007/ s10040-005-0449-2

France, L., Ildefonse, B., and Koepke, J., 2009. Interactions between magma and hydrothermal system in Oman ophiolite and in IODP Hole 1256D: Fossilization of a dynamic melt lens at fast spreading ridges. Geochem. Geophys. Geosyst., 10:Q10O19, doi:10.1029/2009GC002652

Ghent, E. D., and Stout, M. Z., 1981. Metamorphism at the base of the Samail ophiolite, southeastern Oman mountains. J. Geophys. Res., 86(B4):2557-2571. doi:10.1029/JB086iB04p02557

Godard, M., Dautria, J.- M., and Perrin, M., 2003. Geochemical variability of the Oman ophiolite lavas: Relationship with spatial distribution and paleomagnetic directions. Geochem. Geophys. Geosyst., 4:8609. doi:10.1029/2002GC000452

Hacker, B. R., and Gnos, E., 1997. The conundrum of samail: Explaining the metamorphic history. Tectonophysics, 279(1-4):215-226. doi:10.1016/S0040-1951(97)00114-5

Kelemen, P. B., and Hirth, G., 2012. Reaction-driven cracking during retrograde metamorphism: Olivine hydration and carbonation. Earth Planet. Sci. Lett., 345:81-89. doi:10.1016/j. eps1.2012.06.018.

Kelemen, P. B., and Matter, J., 2008. In situ mineral carbonation in peridotite for $\mathrm{CO}_{2}$ storage. Proc. Natl. Acad. Sci. U.S.A., 105(45):17295-17300. doi:10.1073/pnas.0805794105

Kelemen, P. B., Koga, K., and Shimizu, N., 1997. Geochemistry of gabbro sills in the crust-mantle transition zone of the Oman ophiolite: Implications for the origin of the oceanic lower crust. Earth Planet. Sci. Lett., 146(3-4):475-488. doi:10.1016/S0012-821X(96)00235-X

Kelemen, P. B., Matter, J., Streit, E. E., Rudge, J. F., Curry, W. B., and Blusztajn, J., 2011. Rates and mechanisms of mineral car- bonation in peridotite: Natural processes and recipes for enhanced, in situ $\mathrm{CO}_{2}$ capture and storage. Ann. Rev. Earth Planet. Sci., 39:545-576. doi:10.1146/annurevearth-092010-152509

Kelemen, P. B., Shimizu, N., and Salters, V. J. M., 1995. Extraction of mid-ocean-ridge basalt from the upwelling mantle by focused flow of melt in dunite channels. Nature, 375:747-753. doi:10.1038/375747a0

Koepke, J., Schoenborn, S., Oelze, M., Wittmann, H., Feig, S.T., Hellebrand, E., Boudier, F., and Schoenberg, R., 2009. Petrogenesis of crustal wehrlites in the Oman ophiolite: Experiments and natural rocks. Geochem. Geophys. Geosyst., 10:Q10002, doi:10.1029/2009GC002488

Korenaga, J., and Kelemen, P. B., 1997. Origin of gabbro sills in the Moho transition zone of the Oman ophiolite: Implications for magma transport in the oceanic lower crust. J. Geophys. Res., 102(B12):27729-27749. doi:10.1029/97JB02604

Korenaga, J., and Kelemen, P. B., 1998. Melt migration through the oceanic lower crust: A constraint from melt percolation modeling with finite solid diffusion. Earth Planet. Sci. Lett., 156(1-2):1-11. doi:10.1016/S0012-821X(98)00004-1

MacLeod, C. J., and Rothery, D. A., 1992. Ridge axial segmentation in the Oman ophiolite: Evidence from along-strike variations in the sheeted dyke complex. Geol. Soc. London Spec. Publ., 60:39-63. doi:10.1144/GSL.SP.1992.060.01.03

MacLeod, C. J., and Yaouancq, G., 2000. A fossil melt lens in the Oman ophiolite: Implications for magma chamber processes at fast spreading ridges. Earth Planet. Sci. Lett., 176(3-4):357-373. doi:10.1016/S0012-821X(00)00020-0

Manning, C. E., MacLeod, C. J., and Weston, P. E., 2000. Lowercrustal cracking front at fast-spreading ridges: Evidence from the East Pacific Rise and the Oman ophiolite. Geol. Soc. Am. Spec. Pap., 349:261-272. doi:10.1130/0-81372349-3.261

McCollom, T. M., Sherwood-Lollar, B., Lacrampe-Couloumem, G., and Seewald, J. S., 2010. The influence of carbon source on abiotic organic synthesis and carbon isotope fractionation under hydrothermal conditions. Geochim. Cosmochim. Acta, 74(9):2717-2740. doi:10.1016/j.gca.2010.02.008

Ménez, B., Pasini, V., and Brunelli, D., 2012. Life in the hydrated suboceanic mantle. Nature Geosci., 5:133-137. doi:10.1038/ ngeo1359

Neal, C., and Stanger, G., 1985. Past and present serpentinization of ultramafic rocks: An example from the Semail ophiolite nappe of northern Oman. In Drever, J. I. (Ed.), The Chemistry of Weathering: Dordrecht (D. Reidel Publishing Company), 249-275. doi:10.1007/978-94-009-5333-8_15

Nicolas, A., 1986. A melt extraction model based on structural studies in mantle peridotites. J. Petrol., 27(4):999-1022. doi:10.1093/ petrology/27.4.999

Nicolas, A., and Ildefonse, B., 1996. Flow mechanism and viscosity in basaltic magma chambers. Geophys. Res. Lett., 23(16):2013-2016. doi:10.1029/96GL02073

Nicolas, A., and Violette, J. F., 1982. Mantle flow at oceanic spreading centers: Models derived from ophiolites. Tectonophysics, 81:319-339. doi:10.1016/0040-1951(82)90136-6

Nicolas, A., Boudier, F., Ildefonse, B., and Ball, E., 2000. Accretion of Oman and United Arab Emirates ophiolite: Discussion of a new structural map. Mar. Geophys. Res., 21(3-4):147-179. doi:10.1023/A:1026769727917 
Nicolas, A., Reuber, I., and Benn, K., 1988. A new magma chamber model based on structural studies in the Oman ophiolite. Tectonophysics, 151(1-4):87-105. doi:10.1016/0040-1951 (82) 90136-6

Oakley, A. J., Taylor, B., Fryer, P., Moore, G. F., Goodliffe, A. M., and Morgan, J. K., 2007. Emplacement, growth, and gravitational deformation of serpentinite seamounts on the Mariana forearc. Geophys. J. Int., 170(2):615-634. doi:10.1111/j.1365-246X.2007.03451.x

Oeser, M., Strauss, H., Wolff, P. E., Koepke, J., Peters, M., GarbeSchönberg, D., and Dietrich, M., 2012. A profile of multiple sulfur isotopes through the Oman ophiolite. Chem. Geol., 312-313:27-46. doi:10.1016/j.chemgeo.2012.04.008

Okland, I., Huang, S., Dahle, H., Thorseth., I. H., and Pedersen, R. B., 2012. Low temperature alteration of serpentinized ultramafic rock and implications for microbial life. Chem. Geol., 318-319:75-87. doi:10.1016/j.chemgeo.2012.05.015

Paukert, A. N., Matter, J. M., Kelemen, P. B., Shock, E. L., and Havig, J. R., 2012. Reaction path modeling of enhanced in situ $\mathrm{CO}_{2}$ mineralization for carbon sequestration in the peridotite of the Samail Ophiolite, Sultanate of Oman. Chem. Geol., 330-333:86-100. doi:10.1016/j.chemgeo.2012.08.013

Pearce, J. A., Alabaster, T., Shelton, A. W., and Searle, M. P., 1981. The Oman Ophiolite as a Cretaceous arc-basin complex: Evidence and implications. Phil. Trans. Roy. Soc. London, Ser. A, 300 (1454):299-317. doi:10.1098/rsta.1981.0066

Rioux, M., Bowring, S., Kelemen, P., Gordon, S., Dudás, F., and Miller, R., 2012a. Rapid crustal accretion and magma assimilation in the Oman-U.A.E. ophiolite: High precision U-Pb zircon geochronology of the gabbroic crust. J. Geophys. Res., 117:B07201. doi:10.1029/2012JB009273

Rioux, M., Bowring, S., Kelemen, P., Gordon, S., Miller, R., and Dudás, F., 2012b. Tectonic development of the Samail ophiolite: High precision U-Pb zircon geochronology of crustal growth and ophiolite emplacement, J. Geophys. Res., submitted.

Schulte, M., Blake, D., Hoehler, T., and McCollom, T., 2006. Serpentinization and its implications for life on the early Earth and Mars. Astrobiology, 6(2):364-376. doi:10.1089/ ast.2006.6.364

Shock, E. L., 1996. Hydrothermal systems as environments for the emergence of life, In Bock, G. R., and Goode, J. A. (Eds.), Evolution of Hydrothermal Systems on Earth (and Mars): Chichester, U.K. (J. Wiley \& Sons Ltd.), vol. 202, 40-60. doi: 10.1002/9780470514986.ch3

Streit, E., Kelemen, P., and Eiler, J., 2012. Coexisting serpentine and quartz from carbonate-bearing serpentinized peridotite in the Samail Ophiolite, Oman. Contrib. Mineral. Petrol., 164(5):821-837. doi:10.1007/s00410-012-0775-Z

VanTongeren, J. A., Kelemen, P. B., and Hanghøj, K., 2008. Cooling rates in the lower crust of the Oman ophiolite: Ca in olivine, revisited. Earth Planet. Sci. Lett., 267(1-2):69-82. doi:10.1016/j.epsl.2007.11.034

\section{Authors}

Peter Kelemen, Department of Earth \& Environmental Sciences, Columbia University, Lamont Doherty Earth Observatory, 211 Comer, 61 Route 9W, P.O. Box 1000, Palisades, NY 10964-8000, U.S.A., e-mail: peterk@1deo. columbia.edu

Ali Al Rajhi, Geological Survey, Directorate General of Minerals, Ministry of Commerce \& Industry, Oman, e-mail: alialrajhi69@yahoo.com

Marguerite Godard, and Benoit Ildefonse, Géosciences Montpellier, UMR CNRS-UM2 5243 Université de Montpellier II, cc60, Place Eugéne Bataillon, 34095 Montpellier cedex 5, France, e-mail: mgodard@univ-montp2. $\mathrm{fr}$

Jürgen Köpke, Institut für Mineralogie, Leibniz Universität, Callinstr. 3, D-30167 Hannover, Germany, e-mail: koepke@ mineralogie.uni-hannover.de

Chris MacLeod, School of Earth \& Ocean Sciences, Cardiff University, Park Place, Cardiff CF10 3AT, U.K., e-mail: Macleod@cardiff.ac.uk

Craig Manning, Department of Earth \& Space Sciences, UCLA, Los Angeles, CA 90095-1567, U.S.A., e-mail: manning@ess.ucla.edu

Katsu Michibayashi, Institute of Geosciences, Shizuoka University, 836 Oya, Suruga-ku, Shizuoka 422-8529, Japan, e-mail: sekmich@ipc.shizuoka.ac.jp

Sobhi Nasir, Department of Earth Sciences, Sultan Qaboos University, Oman, e-mail: sobhi@squ.edu.om

Everett Shock, Department of Chemistry \& Biochemistry, Arizona State University, Physical Sciences Building, Room D-102, P.O. Box 871604, Tempe, AZ 85287-1604, U.S.A., e-mail: Everett.Shock@asu.edu

Eiichi Takazawa, Department of Geology, Faculty of Science, Niigata University, Nishi-ku, Igarashi, 2-8050, Niigata 950-2181, Japan, e-mail: takazawa@geo.sc.niigata-u. ac.jp

Damon Teagle, National Oceanography Centre, Southampton, University of Southampton Waterfront Campus, European Way, Southampton SO14 3ZH, U.K., e-mail: Damon.Teagle@southampton.ac.uk

\section{Related Web Links}

http://www.iodp.org/abc

http://www.icdp-online.org

http://www.ldeo.columbia.edu/gpg/projects/icdpworkshop-oman-drilling-project

http://www.ldeo.columbia.edu/files/uploaded/image/ Oman\%20mineral\%20carbonation\%20workshop\%20report. pdf

http://www.mohole.org

http://www.iodp.org/700

http://www.iodp.org/science-plan-for-2013-2023

\section{Photo Credits}

All photos of outcrops are by Peter Kelemen 